\title{
AN HISTORICAL SURVEY OF THE LATE-SEASON SNOW-BED IN TUCKERMAN RAVINE, MOUNT WASHINGTON, U.S.A.
}

\author{
By James M. Havens \\ (Dartmouth College, Hanover, New Hampshire, U.S.A.)*
}

\begin{abstract}
As a result of an historical sketch of scientific activity on Mount Washington, New Hampshire, it is shown that the late-season snow-bed that annually forms in Tuckerman Ravine disappeared, on the average, during the first week in August for the period $1922-58$ as compared with an average date of II August for the period 1878-1906. This appears to correspond to a rise in spring (April to May) and summer (June to September) mean temperatures of $0.9^{\circ} \mathrm{F}$. $\left(0.5^{\circ}\right.$ C.) for each season from $1872-87$ to 1933-58. The snow-bed probably has persisted through only one ablation season during recent years, that of 1926 , although some evidence exists that it may have lasted through an occasional summer during the early and middle nineteenth century.
\end{abstract}

Résumé. Après un résumé historique de l'activité scientifique déployéc au Mount Washington, New Hampshire, l'auteur montre que la couche de neige qui se forme chaque année en fin de saison dans le Tuckerman Ravine disparaît en moyenne dans la première semaine d'août pour la période $1022 / 58$ alors que la date moyenne était le 1 I août pour la périoule $187 \% / 1906$. Cela correspond à une élévation des températures moyennes du printemps (avril à mai) et de l'été (juin a septembre) de $0,5^{\circ} \mathrm{C}$ pour chaque saison de $1872 / 87$ à r $933 / 5^{8}$. La couche de neige n'a probablement survécu qu'à une seule saison d'ablation des dernières années, celle de r926, encore que quelques indications fassent penser que cela a anssi pu se répéter occasionnellement pendant le debut et le milieu de XIX ${ }^{\mathrm{e}}$ siècle.

Zusammenfassung. Nachfolgend an einem geschichtlichen Umriss wissenschaftlicher Tätigkeit am Mt. Washington, New Hampshire, wird gezeigt, dass der sich alljährlich im späten Winter in Tuckerman Ravine bildende Schneefleck durchschnittlich in den Jahren 1922-58 während der ersten Augustwoche verschwand im Vergleich zu dem Durchschnittstermin vom i1 ten August in den Jahren 1878-1906. Dies scheint mit einer Erhöhung der Mitteltemperatur im Frühling ( $A$ pril bis Mai) und im Sommer (Juni bis September) um $0,5^{\circ} \mathrm{C}$ für jede Jahreszeit zusammenzuhängen. Der Schneefleck hat wahrscheinlich nur eine Ablationsperiode überdauert, nämlich im Jahre 1926, obwohl ciniges beweist, dass er Anfang und Mitte des neunzehnten Jahrhunderts gelegentlich einen Sommer überdauerte.

\section{INTRODUCTION}

If the present-day glaciation limit in the White Mountains, New Hampshire, were assumed to correspond to the height of the long-term mean $36^{\circ} \mathrm{F}$. $\left(+2^{\circ} \mathrm{C}\right.$.) isotherm surface for June through September, ${ }^{\mathrm{I}}$ it would lie slightly more than $3,000 \mathrm{ft}$. (9ro m.) above the summit of Mount Washington $\left(6,288 \mathrm{ft}\right.$. ( $\mathrm{I}, 9 \mathrm{I} 7 \mathrm{~m}$.)). Manley ${ }^{2}$ has shown that permanent snow-beds are usually found down to only about I, 300 to $\mathrm{I}, 475 \mathrm{ft}$. ( 400 to $450 \mathrm{~m}$.) below the glaciation limit in the maritime region of northwest Europe. One would therefore expect that no permanent snow-beds are to be found in the slightly more continental White Mountains. While this is the case, lingering snow remnants, variously described as snow-beds, snowdrifts, snow patches, and snow cakes, are commonly observed as late as July, particularly on the "knees" of Mount Jefferson, at approximately 4,300 ft. ( 1,3 I $0 \mathrm{~m}$.) and near the bases of the head-walls of the Great Gulf, Huntington Ravine and Tuckerman Ravine (Fig. I). The snow that accumulates at the head of the latter is the most persistent.

Tuckerman Ravine has been described as a compound cirque ${ }^{3}$ with slope discontinuity between the head-wall and the upper floor at approximately 4,500 ft. ( $1,370 \mathrm{~m}$.). The Ravine is of relatively open aspect, and its upper portion trends S.70 $0^{\circ}$. The unmeasured amount of winter accumulation is derived from snow blown across the western slopes, Bigelow Lawn and the rounded summit, from avalanches high up on the head-wall, and from "undisturbed" snowfall. It lasts longer here than in any other area in the eastern United States. During recent years it has disappeared, on the average, during the first week in August, ${ }^{4}$ but it

* 'External' post-graduate student, Bedford College, University of London. 
persisted through the summer of 1926 , "for the first time in the memory of the old timers", 5 and new snow fell on the old in October. There is some indication in the following account that the Tuckerman snow-bed may have survived ablation seasons somewhat more frequently during the early and middle nineteenth century.

\section{Résumé of Historical and Literary Evidence 6, 7, 8}

Most references to late-season snow-beds are found in the journals and reports of mountain walkers, as is also the case for the British mountains by eighteenth and nineteenth century travellers of widely-ranging vocations (see, for instance, refs. 9, ro). Mount Washington also shares the good fortune of being accessible to men who enjoyed literary and scientific pursuits while using their legs as well as their powers of observation. The history of man's meeting with late-surviving snow is here confined to reports from Tuckerman Ravine and is, of course, of comparatively recent date.

Although John Josselyn in 1672 described the White Mountains as those "upon which lieth Snow all the year", ${ }^{11}$ two years later he excepted the month of August, ${ }^{\mathrm{I} 2}$ thus implying that the summit of Mount Washington lies "below the point of perpetual congelation". 13 Over a hundred years elapsed before the first scientific party approached the mountain through Tuckerman Ravine. The group included the Reverend Manasseh Cutler, an enthusiastic member of the American Academy of Arts and Sciences and an early meteorological observer, and Jeremy Belknap, from whose correspondence ${ }^{14}$ and History of New Hampshire come the following observations:

"It was on Friday morning, the 23 rd of July [ I 784], that we set off from Conway ..... The snow had been gone from off the south side of the Mountain but ten days." Belknap comments on the ravines, noting that they "contain a vast quantity of . . . drifted snows, accumulating during the long winter, which begins there generally in September or October, and it must take a long time to dissolve them". The party was guided by a Captain Evans who assured the correspondent that when he was working on the Shelburne Road, Pinkham Notch, in 1774 , some of the work gang "ascended the Mountain, and found snow i 3 feet $[4 \mathrm{~m}$. $]$ deep on the south side, and so hard as to bear them; and that a fortnight after, he went up himself, and there remained 5 feet $[\mathrm{r} \cdot 5 \mathrm{~m}$. $]$ of the snow in the same place". It is probable that this reference is to the Tuckerman snow-bed. The Cutler-Belknap party also ascended the mountain, following Tuckerman Ravine part of the way, but made no report of snow. At this time a Mr. Hight told Belknap that snow was seen on the northwest side of the White Mountains within the past three weeks, but Belknap comments: "The information I believe was mistaken, and instead of 3 , he should have said 5 weeks. I have reason to think, however, and was so informed, that the snow lies longer on the south side, where it is seen at Conway, than on the north or northwest side. The northwest wind blows it over the tops of the mountains, and drives it into the long deep vallies or gullies, where it is formed into a very hard body, 20 or 40 feet [6 or $12 \mathrm{~m}$.] deep or more."

Belknap did not continue with the party to the summit. A main purpose of the visit, the altitude determination of the summit, was undermined by a faulty barometer and the calculated height gave $10,000 \mathrm{ft}$. (3,048 m.).

Although the road built by Captain Evans and his crew improved conditions for further settlement, the preferred route of access to Mount Washington and beyond was for many years farther west through "the Notch", later called Crawford Notch, due largely to the efforts of Abel Crawford and his near-legendary grandson Ethan Allan Crawford. Registers kept at the first Crawford House contain valuable comments made by early travellers who traversed the western slopes, but where lingering snow is seldom found late enough in the season to deserve special comment. ${ }^{15}$ Parties on the eastern slopes frequently had scientific interests, for example the work of Huntington, ${ }^{16}$ but usually no particular references to 
snow-beds were made. However, considerable snow was found in the Great Gulf during the summer of $1829 .{ }^{17}$

In I843 Edward Tuckerman, later Professor of Botany at Amherst College, apparently succeeded in tracing the route taken by the Cutler-Belknap party and carried out botanical collections in the ravine that now bears his name. ${ }^{18}$ From this date the ravine was visited more frequently, although it is still difficult to find specific accounts of the Tuckerman snow-bed.

The completion of the first Summit House in $185^{2}$ and its rival, the Tip-Top House on the summit the following year provided hostelries for tourists. A long-famous collection of

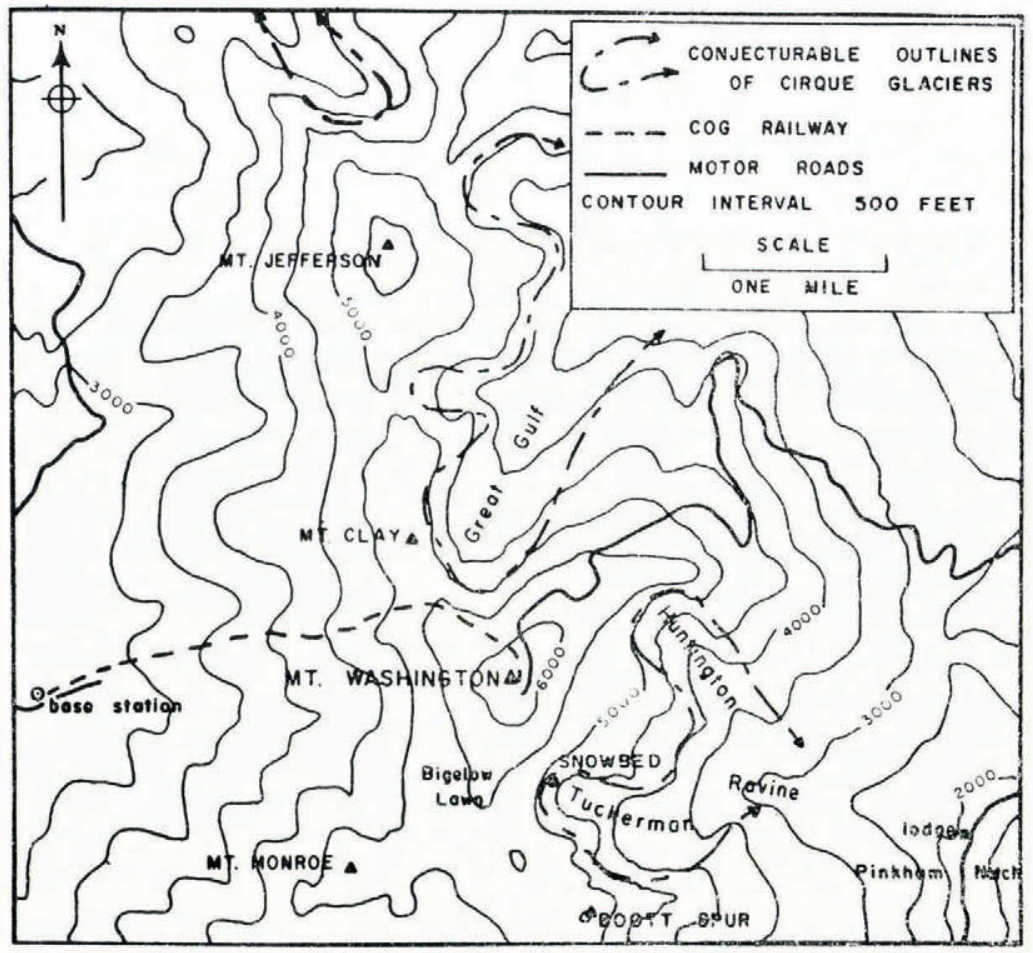

Fig. I. Map of Tuckerman Ravine and vicinity, White Mountains, New Hampshire

travelogue and poetry by Thomas Starr King, The White Hills, appeared in 1860 and undoubtedly encouraged considerable travel to the mountains. The carriage road up the eastern flanks was completed in I86 I and the cog railway, ascending the western slopes, in I869. Although neither permitted a view of the base of the Tuckerman head-wall, each brought a considerable number of tourists to the mountain. Their number has been estimated as 10 to 12 in 1819 , increasing to 7,000 by $1870 .{ }^{19}$

While surveying the route for the carriage road in I854 John H. Spaulding and two companions dined on I6 July under Tuckerman snow-bed's snow arch, an erosional feature which is formed annually by the headwaters of Cutler River and which had become a tourist attraction in its own right by this time. The interior of the arch measured $266 \mathrm{ft}$. (8I m.) by $84 \mathrm{ft}$. (26 m.) and was $40 \mathrm{ft}$. (12 m.) high. ${ }^{20}$

King also reports that he indulged in this novelty, probably in 1855 , when the cave was 
"so high that a tall man could not touch the ceiling with a five-foot staff". The snow-bed itself was measured with a line and its dimensions reported as $294 \mathrm{ft}$. (90 m.) by $66 \mathrm{ft}$. (20 m.) and $15 \mathrm{ft}$. ( $5 \mathrm{~m}$.) deep "where the snow was heaviest".

Thoreau visited the ravine in 1858 , and the following detailed description of the snow-bed (with his rods converted to meters) occurs in his Journal under 7 July: "an irregular crescent on the steep slope at the head of the ravine, some $100 \mathrm{~m}$. wide horizontally, or from north to south, and $42 \mathrm{~m}$. wide from upper to lower side. It may have been $2 \mathrm{~m}$. thick in some places, but it diminished sensibly in the rain while we were there. Is said to be all gone commonly by the end of August. . . . A considerable stream, a source of the Saco, was flowing out from beneath it, where it had worn a low arch a meter and a half or more wide . . .

"The surface of the snow was dirty, being covered with cinder-like rubbish of vegetation, which had blown on it. Yet from the camp [near one of the Hermit Lakes] it looked quite white and pure. For 150 or $200 \mathrm{~m}$., at least, down the stream, you could see the point where the snow had recently melted. It was a dirty-brown flattened stubble, not yet at all greened, covered with a blackish slimy dirt, the dust of the snow-crust." ${ }_{21}$

Thoreau looked at the snow-bed closely and with the eyes of a naturalist. A few years later the geologist C. H. Hitchcock and the astronomer W. H. Pickering regarded it more from a glaciological point of view. Although in the first volume of that monumental collection of treatises, The geology of New Hampshire, Hitchcock mentions "the presence of snow there [Tuckerman Ravine] all through the summer", this is subsequently modified by the following statement: "The snow-arch is the feature which visitors delight to examine. The violent winter winds blow immense quantities of snow from the summit into this ravine, accumulating, it is said, to the depth of hundreds of feet. The enormity of the mass enables it to resist the genial influences of the sun's heat for a long time;--hence it may remain in patches, in favorable seasons, even into September. Usually it is more or less arched, owing to the more comparatively rapid melting next [to] the rivulets. [Fig. 2, p. 723] represents an unusual form, as it appeared August 28, $186{ }_{1},{ }^{, 22}$

The maximum accumulation apparently has never been measured. O'Kane ${ }^{23}$ estimated it to be from 200 to $300 \mathrm{ft}$. ( 60 to $90 \mathrm{~m}$.), while this writer has frequently heard $\mathrm{r} 00 \mathrm{ft}$. ( $30 \mathrm{~m}$.) mentioned as a usual amount. The present snow course of the U.S. Geological Survey does not traverse the area of maximum accumulation. ${ }^{24}$

Probably the first expedition into Tuckerman Ravine with the expressed purpose of studying the snow formation was that of W. H. Pickering in 1879 , who noted that the snowbed "usually" lasted through the middle of August and "has occasionally, I am told, been known to remain till the following winter". On 7 July he found "very large patches" in several places, the largest of which was estimated to measure $\mathrm{I}, 000 \mathrm{ft}$. (300 m.) by $300 \mathrm{ft}$. $(90 \mathrm{~m}$.) and be $100 \mathrm{ft}$. (30 m.) deep in its deepest section. Rock cairns were placed transversely across its surface to ascertain "sliding". The bed was revisited on the 27 th of the month when it was found that much of the snow had melted, its surface was convex, and that the center stones had moved $\mathrm{I} 3 \mathrm{ft}$. ( $4 \mathrm{~m}$.) in 20 days, a rate of $7.8 \mathrm{in}$. $(20 \mathrm{~cm}$.) per day. These observations caused Pickering to remark that "it might, perhaps, be called an incipient glacier". ${ }^{25}$

Pickering's activity in the White Mountains resulted in a map ${ }^{26}$ drawn in 1882 , representing annual summer surveys begun in 1876 . On the map the snow arch is indicated as if it were a permanent feature, at approximately $4,450 \mathrm{ft}$. ( $\mathrm{I}, 35^{\circ} \mathrm{m}$.). Figure $\mathrm{I}$ is based on this map, on Goldthwait's map, ${ }^{3}$ and on the 1955 official map of the Appalachian Mountain Club.

\section{Recent Observations}

For several years, beginning in 1877 , a daily newspaper, Among the Clouds, was published on the summit by F. H. Burt, who, with others, laid out a trail from the summit to the 
Tuckerman snow-bed in $188 \mathrm{I}$. The newspaper frequently contains dates of the collapse of the snow arch and the disappearance of the snow-bed, observed or closely estimated, sufficient to compile the data in Figure 3. The snow appears to last about io days after the collapse of the snow arch. This estimate has been applied when only the collapse date is known. The graph has occasionally been supplemented from other sources 27,28 as, for example, the precise dating of the collapse of the snow arch on 24 July I 886 when it fell on and killed a I5-yearold explorer. ${ }^{29}$

Although the dates of snow disappearance are unknown for several years, in some instances limiting dates can be quoted from Among the Clouds reports. During the summer of

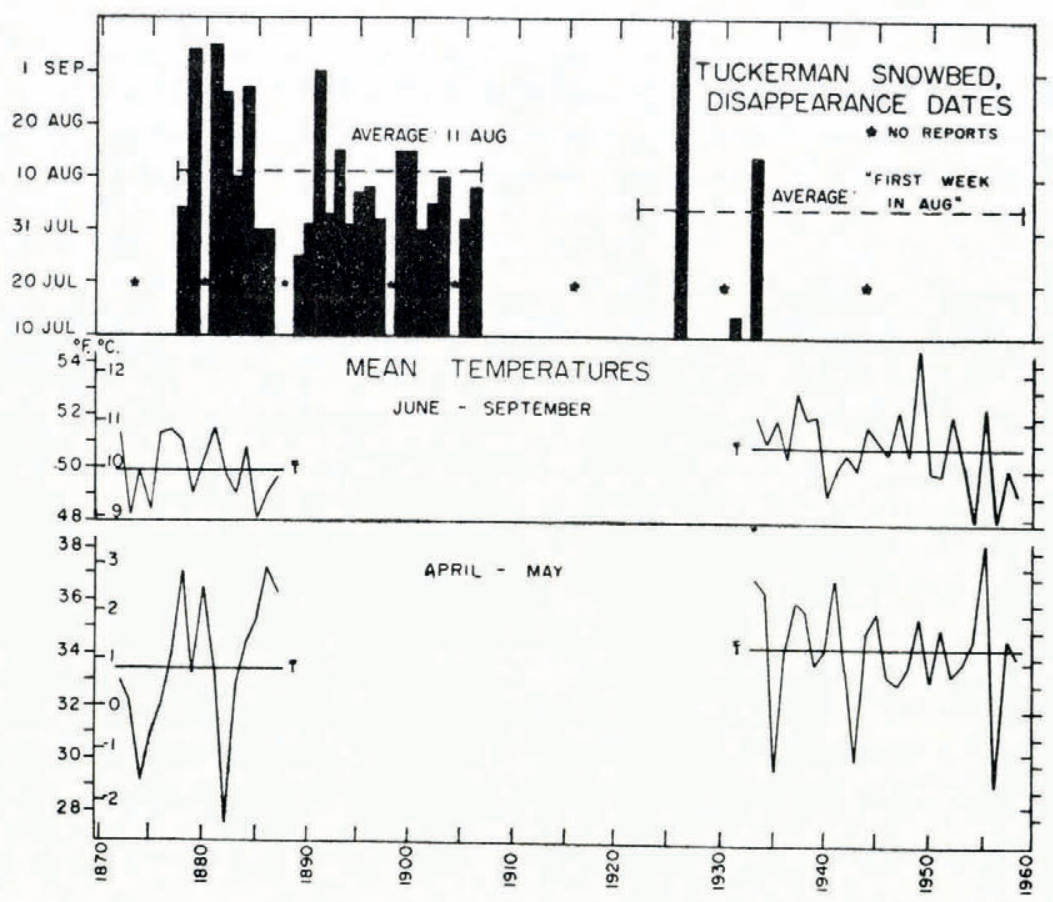

Fig. 3. (top) Probable dates of disappearance of the Tuckerman snow-bed (middle) Mean summer (June-September) temperatures extrapolated to snow-bed altitude, 4,7oo ft. ( $(1,430 \mathrm{~m}$.) from
summit data

(bottom) Same for mean spring (April-May) temperatures similarly extrapolated

I 876 the snow-bed disappeared rather late, sometime after I5 August; I88o was an early season with the snow gone before the first issue of the newspaper on 14 July. In 1887 the snow lasted until after 13 July, while during the following year it remained until after I August. Summer 1898 saw the snow-bed disappear before 26 July.

Mean temperatures are also incorporated into Figure 3 for the two periods April to May and June to September. These data are taken from the Hitchcock Mount Washington Expedition $;^{30}$ U.S. Signal Corps observations; ${ }^{\mathrm{I}}$ and the records of the Mount Washington Observatory. ${ }^{3 \mathrm{I}}$ All mean temperatures have been extrapolated from summit data to $4,700 \mathrm{ft}$. ( $\mathrm{I}, 430 \mathrm{~m}$.), the assumed altitude of the snow-bed, using environmental lapse rates calculated between the summit observatory, 1933 to $195^{2}$, and Pinkham Notch (2,00o ft. (6ro m.)), 
$193^{1}$ to $195^{2.3^{2}}$ For the period April to May this lapse rate is $3.6^{\circ} \mathrm{F}$. $/ \mathrm{r}$, ooo ft. $\left(0 \cdot 65^{\circ} \mathrm{C}\right.$. $)$ $100 \mathrm{~m}$.), for June to September, $3 \cdot 2^{\circ} \mathrm{F}$. $/ \mathrm{I}$, ooo ft. $\left(0.58^{\circ} \mathrm{C}\right.$. $/$ ioo m. $)$.

Mr. Guy L. Shorey has kindly permitted reproduction of the photograph in Figure 4, (p. 723), showing the snow-bed and arch on 3 September 1926, the year the snow is said to have lasted through the entire summer season. 5 From monthly maps of temperature anomaly 33 it is estimated that the April to May mean temperature in 1926 was $3.5^{\circ} \mathrm{F}$. $\left(\mathrm{I} \cdot 9^{\circ} \mathrm{C}\right.$.) below normal and that the June to September mean temperature was at least $2^{\circ} \mathrm{F}\left(\mathrm{I} \cdot \mathrm{I}^{\circ} \mathrm{C}\right.$. $)$ below normal.

Mr. R. L. Lavoie visited the snow-bed for the writer on 4 July in the warm summer of I 955 and reported its surface shape as describing an approximate parallelogram with diagonals $300 \mathrm{ft}$. $(90 \mathrm{~m}$.) and $200 \mathrm{ft}$. $(60 \mathrm{~m}$.) respectively and a maximum depth of about I 5 to $18 \mathrm{ft}$. ( 4 to $5 \mathrm{~m}$.). The U.S. Forest Service took a photograph of the snow-bed on the 2oth of that month by which time its dimensions were considerably reduced. Its general appearance was similar to that for 3 September 1926 but with slightly less snow.

Considerably more snow was in the ravine at the start of the $195^{8}$ summer. On the summit 344 in. $(874 \mathrm{~cm}$.) of snow (unmelted) were recorded for the previous winter, the greatest total since observations began at the Mount Washington Observatory in 1932. At Hanover, New Hampshire, about 60 miles (100 km.) to the south-west, the snowfall during $1957-58$ set a 92 -year record with I $18 \mathrm{in}$. (300 cm.), 44 in. ( I I $2 \mathrm{~cm}$.) above the average for the period. With spring and summer temperatures below normal it might be expected that the snow would last until late in the season. No record is available, however. A set of U.S. Forest Service slides shows considerable snow at the site on 2 I July but perhaps not an unusually great amount. June averaged about $5^{\circ} \mathrm{F}$. $\left(2 \cdot 8^{\circ} \mathrm{C}\right.$. $)$ colder than the period mean, but July through September were close to normal, probably the main reason for the season not attracting attention as one of unusually late snow survival.

\section{Discussion and Conclusions}

Historical evidences of the survival of the Tuckerman snow-bed are most numerous for the 30 years following the founding of the Appalachian Mountain Club in 1876 and during the publication of Among the Clouds. Since that period of late Victorian exploration, the incentive to record the snow-bed appears to have diminished. However, spring and early summer skiing became popular subsequent to the 1920's, aided by the Appalachian Mountain Club Lodge, built in Pinkham Notch in 1926, and various shelters constructed in the ravine. Skiers are understandably interested in the lasting-power of their sport material, see for example ref. 28 .

The average date of disappearance of the snow-bed has been estimated as "during the first week in August" by Mr. Joseph B. Dodge, former White Mountain hut manager of the Appalachian Mountain Club and resident in the area from 1922 to I958. This date is one week earlier than that for the period 1878 to 1906 . Statements dating the disappearance in late August or early September are probably based on the unusually late seasons of I868, 1879 and 1881 and represent no "averaging" in time.

Data are insufficient to establish the existence of any definite trend toward a shorter snow-bed season during recent years although this might be inferred from Figure 3. Slightly higher spring and summer mean temperatures are, however, compatible with the "first week in August" snow-bed disappearance estimate as compared to I I August. To compound this uncertainty, no information exists on accumulation totals, which probably vary considerably from year to year. The r 880 report by Pickering, that the snow-bed had been known to last "occasionally" through individual summers could refer to seasons during the early and middle nineteenth century.

The summit of Mount Washington has received increased attention since the establish- 
ment of the Mount Washington Observatory. Both the observatory and the Pinkham Notch lodge can be looked upon as future bases for snow-bed study in the ravine. Snow-beds, even where they are non-permanent, reflect marginal climatological conditions for their survival and are, therefore, worthy of investigation. However, the writer knows of only one instance of meteorological observations recently carried out at the site of snow-beds in a non-glacierized region. ${ }^{34}$

\section{Acknowledgements}

The writer wishes to acknowledge the help of the many individuals and organizations that aided the search for historical evidence of late snow survival in the White Mountains. Although space does not allow specific mention of them, their help is in no way less appreciated. Helpful criticisms concerning parts of the paper were received from Professor Gordon Manley, Bedford College and from Dr. Van H. English, Dartmouth College. The cost of its preparation was supported by the Committee on Research, Dartmouth College.

\section{MS. received ${ }_{15}$ March 1960}

\section{REFERENGES}

1. Antevs, E. Alpine zone of Mt. Washington range. Auburn, Maine, Merrill and Webber Co., 1932. 118 p.

2. Manley, G. The snowline in Britain. Geografiska Annaler, Arg. 31, Ht. 1-4. 1949, p. 179-93.

3. Goldthwait, R. P. Geology of the Presidential Range. Bulletin. New Hampshire Academy of Science, No. 1, 1940, p. I-4I.

4. Dodge, J. B. Personal communication.

5. MacGregor, M. E. An early accident in Tuckerman Ravine. Appalachia, New Scries, Vol. 16, 1950, p. 1 I 3-14.

6. Bent, A. H. A bibliography of the White Mountains. Boston, Mass., Houghton Mifllin Co., 1911. I14 p.

7. Wright, W. W. The White Mountains: an annotated bibliography, 1918-1947. Appalachia, New Series, Vol. 14, 1948, p. 205-23.

8. Kilbourne, F. W. Chronicles of the While Mountains. Boston, Mass., and New York, Houghton Mifflin Co., 1916. 434 p.

9. Manley, G. Dorothy Wordsworth's weather. Weather, Vol. 2, 1947, p. 361-64.

10. Manley, G. John Dalton's snowdrift. Weather, Vol. 7, No. 7, 1952, p. 210-12.

I I. Josselyn, J. New England's rarities discovered. London, G. Widclowes, 1672.114 p.

12. Josselyn, J. An account of two voyages to New England. London, G. Widdowes, I674. 279 [i.e. 277$]$ p.

13. Williams, S. The natural and civil history of Vermont. Walpole, N. H., I. Thomas and V. (iarlisie, jun., 1 794. 4 I 6 p.

14. Belknap, J. Collections of the MAassachusetts Historical Society, Fifth Series, Vol. 2, 1877, p. 387-94; Vol. 3, 1877. p. $170-77$.

15. Tuckerman, F. Gleanings from the visitor's albums of Ethan Allen Crawford. Appalachia, Vol. 14, No. 4, 1919, p. $367-83$

16. Huntington, J. H. The flowering plants of the White Mountains. Appalachia, Vol. 1, No. 2, 1877, p. $100-06$.

17. Pease, A. S. Notes on the botanical exploration of the White Mountains. Appalachia, Vol. 14, No. 2, 1917 , p. $157-79$.

18. Tuckerman, E. Exploration of the White Hills. (In King, T. S. The White Hills [ref. 20], p. 34-46.)

19. Upham, W. History of explorations among the White Mountains. (In Hitchcock, C. H.. and others. The geolog; of New Hampshire. Vol. 1, Pt. 1, 1874 [ref. 22], p. 59-118.)

20. King, T. S. The White Hills: their legends, landscape, and poetry. Boston, Mass., Crosby, Nichols, Lec and Co., 1860. 403 p.

21. Thoreau, H. D. The journal of Henry D. Thoreau. Vol. 2. [Edited by B. Torrey.] Boston, Mass., Houghton Mifflin Co., I906, p. I-41.

22. Hitchcock, C. H., and Huntington, J. H. In Hitchcock, C. H., and others. The geology of New Hampshire. Vol. I, Pt. I. Physical geography. Concord, N.H., E. A. Jenks, i 874 , p. 623-24.

23. O'Kane, W. C. Trails and summits of the White Mountains. Boston, Mass., and New York, Houghton Mifflin Co., 1925 , p. 65 .

24. U.S. Weather Bureau. Snow cover surveys, 1957-1958. Washington, D.C., U.S. Government Printing Office, I959. $22 \mathrm{p}$.

25. Pickering, W. H. A three days' tramp on the Mount Washington range. Appalachia, Vol. 2, No. 2, 188o, p. II 7-2I.

26. Pickering, W. H. A contour map of the Mount Washington range. Appalachia, Vol. 3, No. 1, r882, p. 54-57.

27. Whitman, M. F. A climb through Tuckerman's ravine. Appalachia, Vol. 1, No. 3, 1877, p. $131-37$.

28. Fowler, W. P. Spring and summer skiing in New England. Appalachia, Vol. 27, No. 4, 1933, p. 524-36. 
29. Mount Washington Observatory News Bulletin, No. 25, 1954, p. 7-8.

30. Hitchcock, C. H., and others. Mount Washington in winter, or the experiences of a scientific expedition upon the highest mountain in New England, I870-7I. Boston, Mass., Chick and Andrews, I871. 363 p.

31. U.S. Weather Bureau. Local climatological data, Mount Washington, N.H. Washington, D.C., U.S. Government Printing Office, 1958.

32. U.S. Weather Bureau. Climatic summary of the United States. Supplement for I931 through 1952. Washington, D.C., U.S. Government Printing Office.

33. Monthly Weather Review (U.S. Weather Bureau), Jan.-Oct., I926.

34. Baird, P. D. Weather and snow on Ben Macdhui. Cairngorm Club Journal, Vol. 1 7, No. 91, 1957, p. 147-49. 


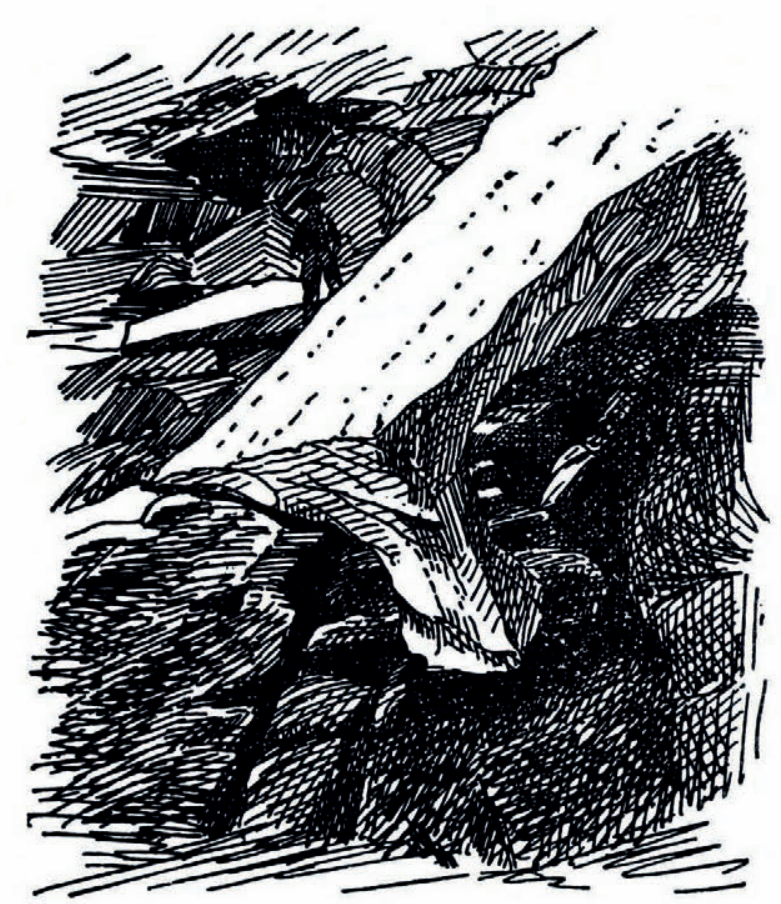

Fig. 2. Tuckerman snow-bed on 28 August $186 \mathrm{I}$, from Hitchcock 22

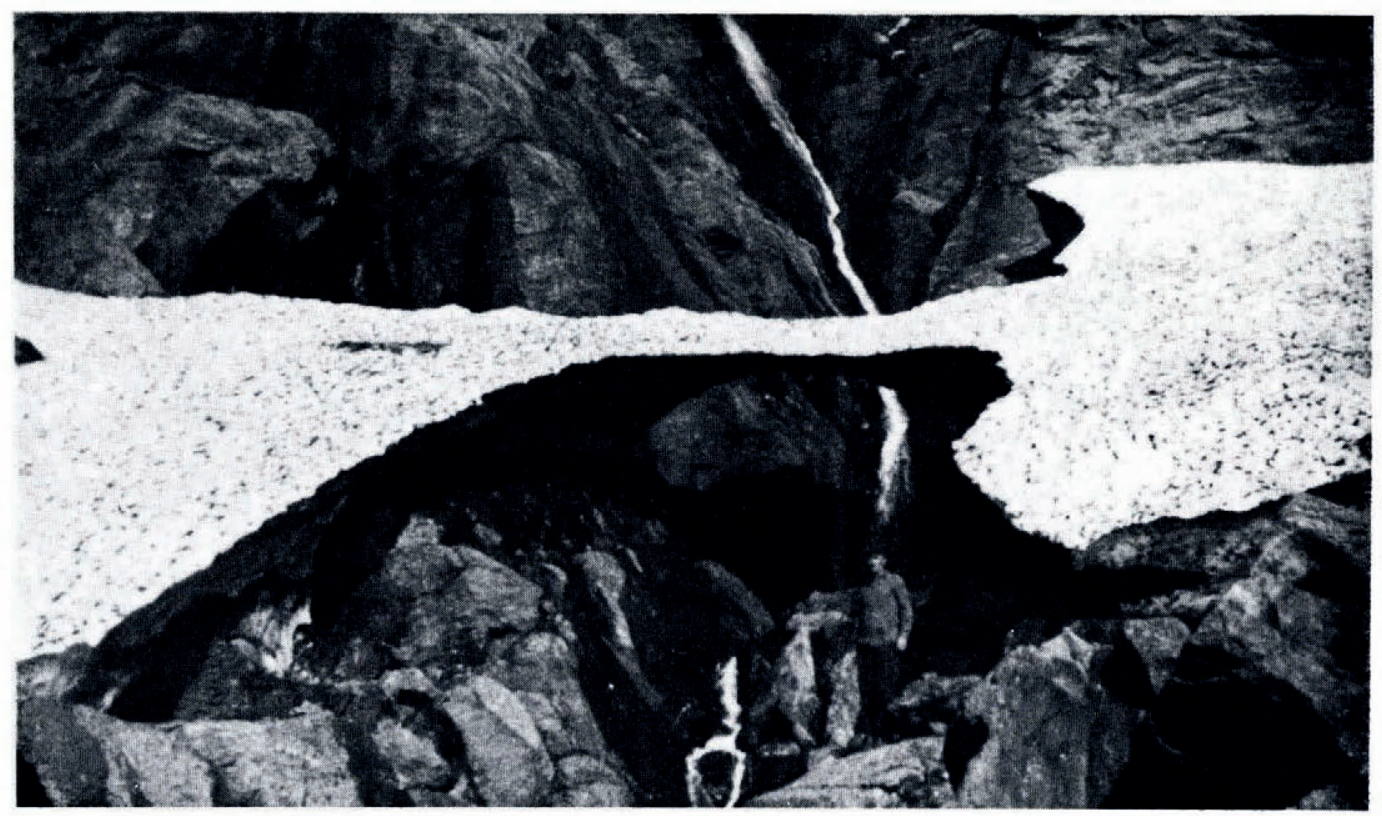

Fig. 4. Tuckerman snow-bed on 3 September 1926. (Photograph by Guy L. Shorey) 